\title{
Techno-Economic Analysis of Hybrid Drainage Systems in South Australia
}

\author{
Faisal Ahammed, Christian Somerville, Fergus Hamilton, and Robert Beardwell
}

\begin{abstract}
The primary purpose of the Conventional Drainage System (CDS) is flood management; its primary focus is the rapid collection of stormwater runoff from all impervious surfaces and its discharge into the nearby water systems. Therefore, the system overlooks important utilization of stormwater as a valuable water resource. On the other hand, Water Sensitive Urban Design (WSUD) - an Australian innovation of sustainable urban water cycle management, is a decentralized stormwater management tool that aims to minimise hydrological impacts of urban development on the surrounding environments. A Hybrid Drainage System (HDS) is the combination of CDS and WSUD technologies. CDS and infiltration based WSUD technologies were designed using DRAINS and Argue's source control principles respectively for stage 1 of the Strathalbyn Residential Sub-division Project, which is located $60 \mathrm{~km}$ southeast of Adelaide CBD and consists of 55 residential allotments. Costings of CDS and WSUD technologies for 20 years life cycle were estimated using Rawlinson's Construction Handbook and a MUSIC (Model of Urban Stormwater Improvement Conceptualization), respectively. Historical water utility price was collected from SA Water to quantify the economic benefits of HDS. The benefit cost analysis of the designed technologies of HDS was performed using net present value, benefit cost ratio and internal rate of return and found that HDS is economically feasible for the project site. Results from monthly basis continuous simulations of three most critical rainfall events (December 1992, June 2005 and June 2012) show that HDS is also capable of reducing the flooding risk. Therefore, HDS could be the solution of everyday problems of stormwater management - quantity control (flood management), quality control (pollution management) and stormwater harvesting.
\end{abstract}

Index Terms-Hybrid drainage system, technical analysis, economic benefits, flood management, stormwater management.

\section{INTRODUCTION}

It was found in the 1990s that conventional stormwater management policies approved by councils inevitably led to increased urban flooding [1]. In a severe storm; excess runoff is created from increased impervious surfaces, such as housing allotments, roads, driveways, parking lots, sidewalks and rooftops. As a result of the highly impervious surface areas, rainfall and runoff infiltration is decreased, and water volume and peak flow is increased [2]. The increased pressure on the Conventional Drainage System (CDS) can create flooding in streets and increase urban-generated

Manuscript received August 24, 2016; revised December 19, 2016.

The authors are with School of Natural and Built Environments, University of South Australia, Australia (e-mail: FaisalAhammed.Ahammed@unisa.edu.au). pollution [3]. The consequence of this puts more stress on urban water systems and adversely changes the hydrological cycle in urban catchments. The primary feature of Water Sensitive Urban Design (WSUD) is that the complete water cycle is taken into consideration in urban design [4]. The use of WSUD in urban stormwater harvesting represents an opportunity to provide a new water resource whilst capping the amount of stormwater that is sent to the CDS. The decrease in demand on drainage will have follow on effects by protecting waterways from pollution and ecosystem degradation [5].

Implementing disseminated stormwater management measures such as WSUD technologies could reduce the average household's water consumption, thus saving money, improve water quality through biological processes, in-turn reducing environmental impacts and potentially increase the visual amenity of urbanised areas. Hybrid Drainage System (HDS), a mixture of CDS and WSUD, involves collecting a portion of stormwater runoff and re-diverting it to WSUD measures such as infiltration devices, where the water will collect, infiltrate and be retained, ultimately promoting evapotranspiration, the recharge of groundwater and reuse [6].

In this study, CDS and infiltration based WSUD technologies were designed using DRAINS and Argue's source control principles [1] respectively. Infiltration systems are designed and constructed to capture and infiltrate stormwater runoff into surrounding soils and underlying groundwater [7], [8]. Usually the systems are wrapped with geo-textile fabric to prevent ingress of local soil. Infiltration systems can control floods by reducing the surface runoff volume and dispersing the peak flows [1], [7]-[10]. A study conducted by Yazdi and Scholz [10] in Edinburgh, Scotland observed $73 \%$ reduction of mean flow volume and $80 \%$ reduction of mean peak flow using infiltration systems. They can also be used for capturing dissolved pollutants [1], [11]. Life spans of these systems are around 20 years [9], [12]. There are three basic types of infiltration systems: leaky wells, soakaways and infiltration trenches, which are used for effective stormwater management in Australia [1], [9]. Leaky wells, used in small scale residential sites, consist of large diameter perforated pipes or wells that allow infiltration of stormwater into the surrounding soils [13]. Soakaways are also underground infiltration structures filled with materials such as gravel or sand and perforated plastic pipes; they provide temporary storage for stormwater runoff from roofs and allow infiltration of stormwater into the surrounding soils [14]. Infiltration trenches consist of excavations that are 0.5 to $1.5 \mathrm{~m}$ deep, filled with gravel or modular plastic cells; these are lined with geo-textile cloth and backfilled to a depth of around $0.3 \mathrm{~m}$ [15]. Fig. 1 shows three different types of infiltration based WSUD technologies. 
The aim of this study was to conduct a techno-economic analysis of HDS for urban environments, consisting of

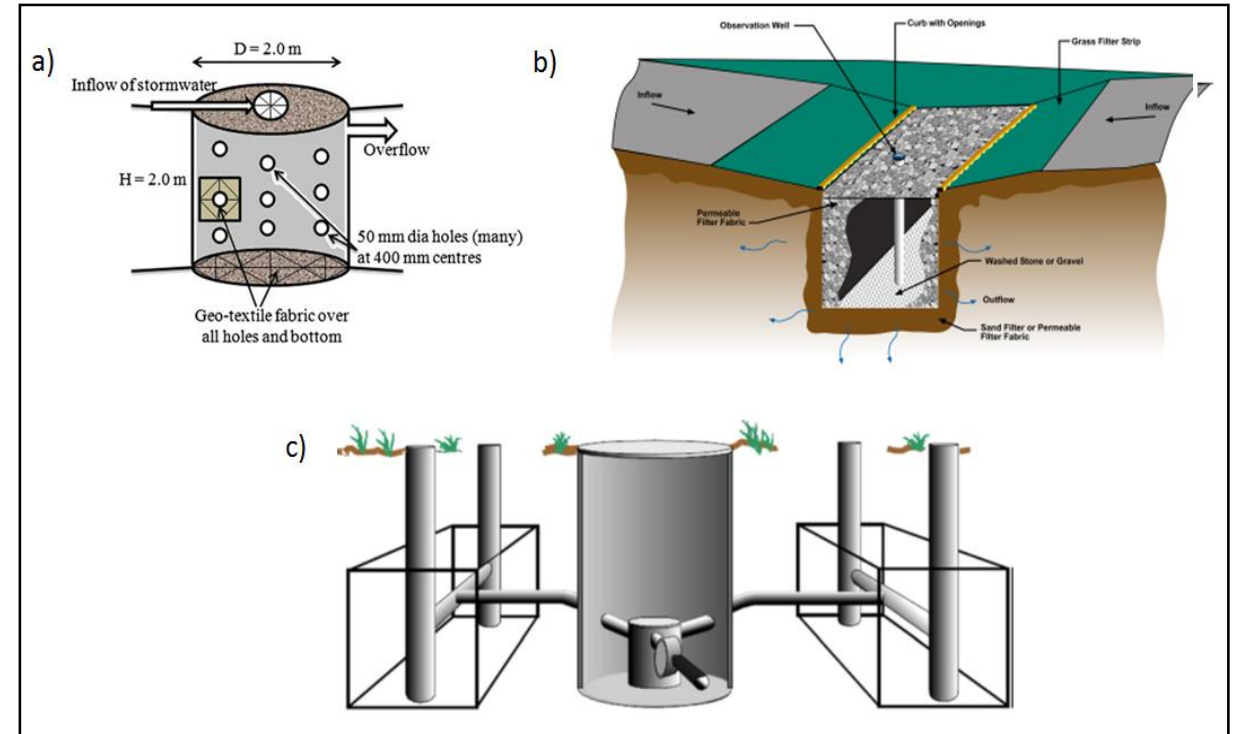

Fig. 1. a) Leaky well [16]; b) soakaway [16] and c) infiltration trench [14].

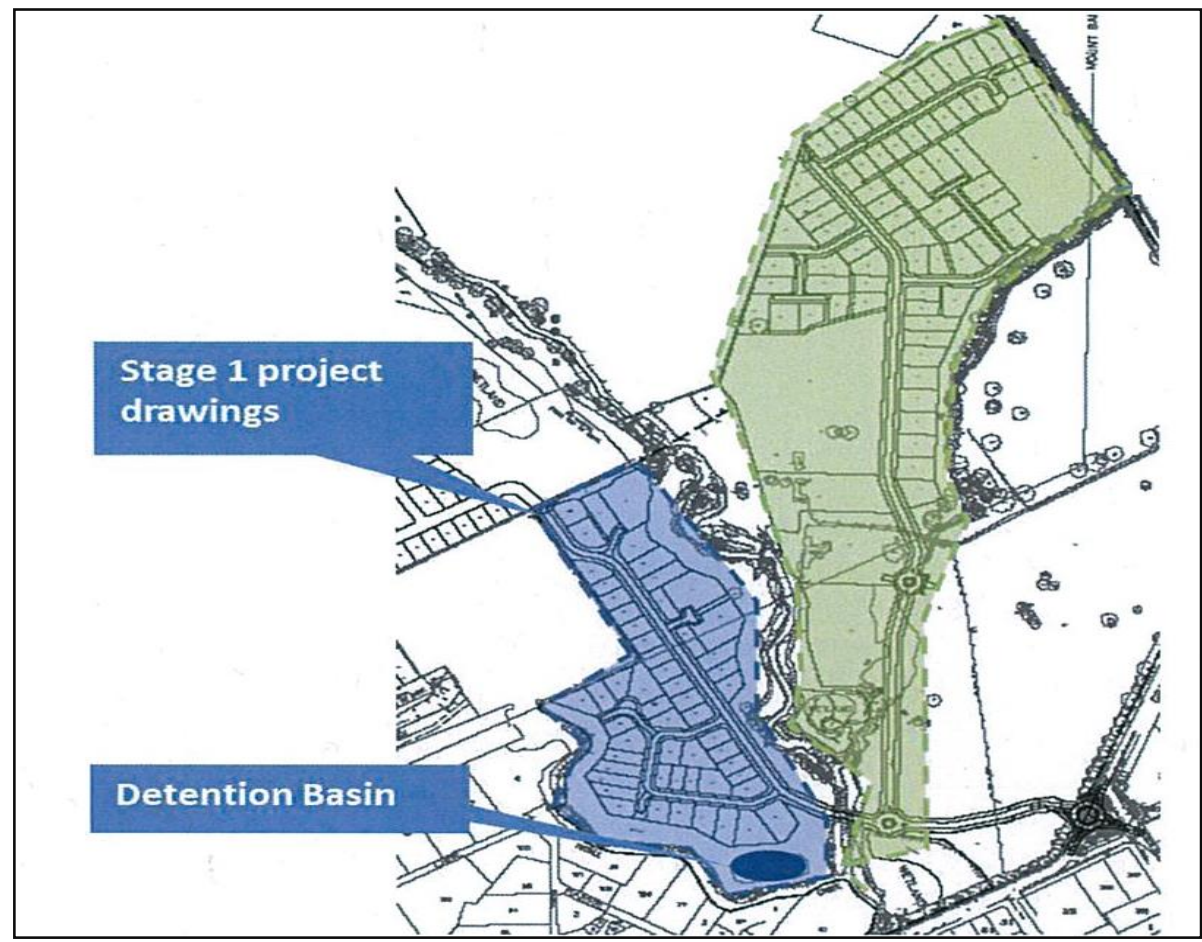

Fig. 2. Study area: stage 1 of residential sub-division of Strathalbyn, South Australia.

\section{Study AREA AND Methodology}

\section{A. Study Area}

The trial study area (Fig. 2) was the stage 1 of Strathalbyn Residential Sub-division Project, which is located $60 \mathrm{~km}$ southeast of Adelaide CBD and consists of 55 residential allotments. The overall sub-division consists of 123 allotments. The average allotment size of the project area is around $1000 \mathrm{~m}^{2}$. The annual average rainfall of the study area is $491 \mathrm{~mm}$ and the rainfall intensity for 100 years average recurrence interval and 1 hour duration is around $46 \mathrm{~mm} / \mathrm{h}$ [17]. The portions of impervious and pervious areas after the development was estimated as $76 \%$ and $24 \%$ respectively.

\section{B. Design of Infrastructure}

It was assumed in the design process that roof accepted stormwater runoff would be managed by infiltration based WSUD technologies and the remaining amount of runoff would be diverted in the drainage systems. Infiltration based WSUD technologies (leaky well, soakaway and infiltration trench) were designed based on Argues' source control principles [1]. Equations 1-3 show the formulas for designing leaky well, soakaway and infiltration trenches respectively.

$$
\begin{aligned}
& D=\sqrt{\frac{V}{\frac{\pi(H+120 \cdot K h \cdot \tau \cdot U)}{4}}} \\
& A=\frac{V}{e \cdot H+60 \cdot K h \cdot \tau \cdot U}
\end{aligned}
$$




$$
L=\frac{V}{\left[e \cdot b \cdot H+60 \cdot K h \cdot \tau \cdot\left(b+\frac{H}{2}\right) \cdot U\right]}
$$

where,

$\mathrm{D}=$ diameter of leaky well,

$\mathrm{A}=$ area of soak-away,

$\mathrm{L}=$ length of infiltration trench,

$\mathrm{b}=$ width of infiltration trench,

$\mathrm{H}=$ height of leaky well/ soakaway / infiltration trench,

$\mathrm{V}=$ stormwater runoff volume of critical duration,

$\mathrm{K}_{\mathrm{h}}=$ soil hydraulic conductivity,

$\tau=$ critical storm duration $\left(\mathrm{t}_{\mathrm{c}}\right)+$ site time of concentration $\left(\mathrm{t}_{\mathrm{s}}\right)$,

$\mathrm{U}=$ moderation factor; $0.5,1.0$ and 2.0 for sandy, sandy clay and clay soil respectively.

It is important to ensure that the stored runoff within WSUD system is empty before the arrival of a succeeding significant storm [18]. Emptying times of leaky-wells, soakaways and infiltration trenches were estimated using Equations 4-6 respectively [1]. The recommended value is around 1 day for New Zealand [19] and 3 days for the USA [20]. In the UK, the usual practice suggests that $50 \%$ of the stormwater storage to be emptied within 24 hours [21]. Davis et al. [22] recommended the value of emptying time as 72 96 hours depending on the patterns of regional rainfalls. In Australia, this value varies from 12 hours to 3.5 days depending on the frequencies of ARI [1].

$$
\begin{gathered}
T_{e}=-\frac{4.6 D}{4 K h} \log \left[\frac{\frac{D}{4}}{H+\frac{D}{4}}\right] \sec \\
T_{e}=\frac{2 \cdot H \cdot e}{K h} \sec \\
T_{e}=\frac{-4.6 L \cdot b \cdot e}{2 K h(L+b)} \log _{10}\left[\frac{L . b}{L \cdot b+2 H(L+b)}\right] \mathrm{sec}
\end{gathered}
$$

The CDS was designed using DRAINS model. Sub-catchments, pits, pipes, overflow routes and nodes were selected using ILSAX model in DRAINS and optimum pipe sizes were adopted.

\section{Methodology for Economic Analysis}

Historical water utility price for the duration of 1995 to 2015 was collected from SA Water (water supply authority) to quantify the economic benefits of HDS. Costings of CDS and WSUD technologies for a 20 years life cycle were estimated using Rawlinson's Construction Handbook and MUSIC (Model of Urban Stormwater Improvement Conceptualization), respectively. Economic analysis of HDS was performed using net present value (NPV), benefit cost ratio (BCR), internal rate of return (IRR) and discounted pack back period. NPV of a project is the sum of discounted values of a stream of net cash flows generated by a project during its life period and if the estimated NPV is greater than zero, the project could be economically feasible [23]. BCR is the ratio of present value benefits to initial investment; if BCR is greater than one, the project could be economically accepted. IRR is the rate of discount that equates the present value of net cash flows equal to the initial investment cost of a project. If IRR is less than the cost of capital, the project could be rejected [24]. Payback period is the length of time required to recover the initial cash outlay on the project. The method also serves as a proxy for risk. The faster the investment is recovered, the less risk to which the project is exposed [23]. Estimations of NPV, BCR, IRR and discounted payback period require converting the future case benefits into present benefits and it was performed using eqn (7).

$$
P V=\frac{F V}{(1+r)^{n}}
$$

where,

$$
\begin{aligned}
& P V=\text { present benefit } \\
& F V=\text { future benefit } \\
& r=\text { discount rate } \\
& n=\text { number of years }
\end{aligned}
$$

\section{RESUltS AND DisCUSSIONS}

\section{A. Technical Analysis}

The dimensions and emptying times of the designed infiltration based WSUD technologies for a 20 years ARI situation are shown in Table I.

TABLE I: DIMENSIONS AND EMPTYING TIMES OF INFILTRATION BASED

\begin{tabular}{|ccc|}
\hline $\begin{array}{c}\text { INFILTRATION BASED } \\
\text { WSUD } \\
\text { TECHNOLOGIES }\end{array}$ & DIMENSIONS & EMPTYING TIMES \\
\hline LEAKY WELL & $(\mathrm{M})$ & $($ HRS $)$ \\
\hline & $\begin{array}{c}\text { DEPTH }=2 \\
\text { DIAMETER }=2\end{array}$ & 15 \\
\hline SOAKAWAY & $\begin{array}{c}\text { HEIGHT }=0.5 \\
\text { WIDTH }=3 \\
\text { LENGTH }=3\end{array}$ & 8 \\
\hline & $\begin{array}{c}\text { HEIGHT }=0.5 \\
\text { WIDTH }=1\end{array}$ & 6 \\
INFILTRATION & LENGTH $=7$ & \\
TRENCH & & \\
\end{tabular}

The most three critical rainfall months for the project site were found as December 1992, June 2012 and June 2005. The continuous simulation of these critical rainfall events was performed and no overflow was observed for the designed infiltration based WSUD technologies.

The long section of drainage pipes using DRAINS model for HDS is shown in Fig. 3. The selected concrete pipe sizes at up-stream and down-stream are 375 and $600 \mathrm{~mm}$ respectively. The hydraulic grade line represents that theoretically no up-welling of water through pits could occur; thus, there is very little risk of flooding.

\section{B. Economic Analysis}

Fig. 4 shows the historical prices of water utility in South Australia. It was observed from Fig. 4 that water utility prices were suddenly increased during the period of 2008 to 2013.

It was estimated that the installation of infiltration based WSUD technologies would require a $\$ 23,645$ investment for the project site. The total discounted economic benefit due to infiltration of stormwater into the surrounding soil was estimated as $\$ 107,190$. The estimated values of NPV, BCR, IRR and discounted pay back periods were $\$ 83,925,4.61,32 \%$ and 4 years respectively. This part of analysis (shown in Appendix A) confirmed that HDS are economically feasible in the project site. 


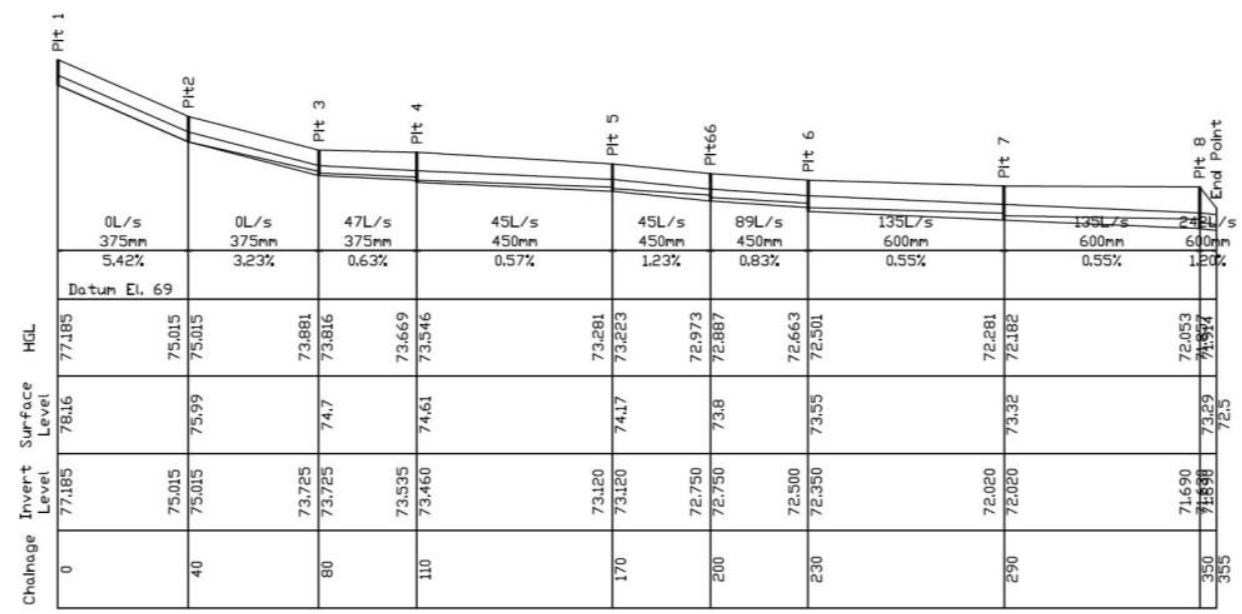

Fig. 3. Long section of drainage pipes for HDS.

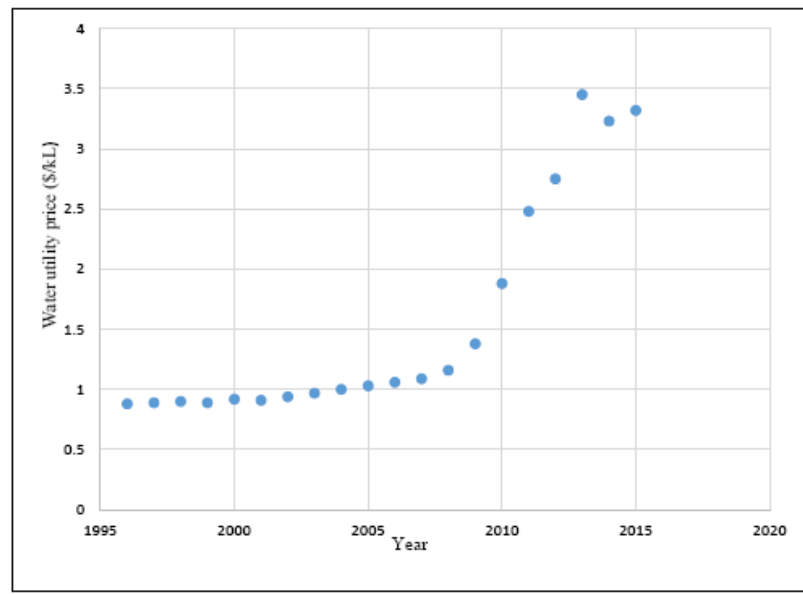

Fig. 4. Historical prices of water utility in South Australia.

\section{CONCLUSIONS}

This paper illustrated techno-economic analysis of HDS in South Australian context. The main focus in this investigation was to determine the functionality of HDS for a trial catchment for 1 in 100 year rainfall events. Through the simulation of DRAINS, it was found that the system is capable of managing runoff quantity in major storms for 1 in 100 ARI year events. Infiltration based WSUD technologies were designed using Argue's source control principles [1] to divert roof accepted runoff away from the drainage systems. Economic analysis of HDS was performed through the estimation of NPV, BCR, IRR and discounted payback period. This part of analysis revealed that HDS is economically feasible for household, council and business purposes. A further investigation is required to understand and increase social acceptability of HDS.

APPENDIX

ECONOMIC ANALYSIS OF HDS

\begin{tabular}{ccccc}
\hline $\begin{array}{c}\text { No. } \\
\text { of } \\
\text { years }\end{array}$ & Years & $\begin{array}{c}\text { Economic } \\
\text { benefit (AU\$) }\end{array}$ & $\begin{array}{c}\text { Discounted } \\
\text { benefit (AU\$) }\end{array}$ & $\begin{array}{c}\text { Cumulative } \\
\text { discount benefit } \\
\text { (AU\$) }\end{array}$ \\
\hline 1 & 2016 & 6792 & 6468 & 6468 \\
2 & 2017 & 7021 & 6368 & 12837 \\
3 & 2018 & 7250 & 6263 & 19099
\end{tabular}

\begin{tabular}{|c|c|c|c|c|}
\hline 4 & 2019 & 7479 & 6153 & 25252 \\
\hline 5 & 2020 & 7708 & 6039 & 31291 \\
\hline 6 & 2021 & 7937 & 5922 & 37214 \\
\hline 7 & 2022 & 8166 & 5803 & 43017 \\
\hline 8 & 2023 & 8395 & 5682 & 48698 \\
\hline 9 & 2024 & 8623 & 5559 & 54257 \\
\hline 10 & 2025 & 8852 & 5435 & 59692 \\
\hline 11 & 2026 & 9081 & 5310 & 65001 \\
\hline 12 & 2027 & 9310 & 5184 & 70186 \\
\hline 13 & 2028 & 9539 & 5059 & 75245 \\
\hline 14 & 2029 & 9768 & 4934 & 80178 \\
\hline 15 & 2030 & 9997 & 4809 & 84987 \\
\hline 16 & 2031 & 10226 & 4685 & 89672 \\
\hline 17 & 2032 & 10455 & 4561 & 94233 \\
\hline 18 & 2033 & 10684 & 4439 & 98673 \\
\hline 19 & 2034 & 10913 & 4319 & 102991 \\
\hline 20 & 2035 & 11142 & 4199 & 107190 \\
\hline \multicolumn{3}{|c|}{ Total discounted benefit $=$} & 107190 & \\
\hline & & Investment $=$ & 23265 & \\
\hline & & $\mathrm{NPV}=$ & 83925 & \\
\hline & & $\mathrm{BCR}=$ & 4.61 & \\
\hline & & $\mathrm{IRR}=$ & $32 \%$ & \\
\hline \multicolumn{3}{|c|}{ Discounted payback period $=$} & 4 years & \\
\hline
\end{tabular}

\section{REFERENCES}

[1] J. R. Argue, "Water sensitive urban design: basic procedure for source control of stormwater: A handbook for Australian practice," University of South Australia, 2013. 
[2] J. B. Mikula, S. E. Clark, and K. H. Baker, "Modelling Zinc and Sodium Chloride migration vadose zone Soils beneath stormwater infiltration devices," in Proc. the Annual International Conference on Soils, Sediments, Water and Energy, vol. 11, pp. 1-15, 2010.

[3] F. Ahammed, G. Hewa, and J. Argue, "Introducing leaky-well concept for stormwater quantity control in Dhaka, Bangladesh," Applied Water Science, vol. 3, no. 1, pp. 115-123, 2013.

[4] J. Kunapo, S. Chandra, and J. Peterson, "Drainage network modelling for water sensitive urban design," Transactions in GIS, vol. 13, no. 2 , pp. $167-178,2009$.

[5] Q. Weng, "Remote sensing of impervious surfaces in the urban areas: Requirements, methods, and trends,"Remote Sensing of Environment, vol. 117, no. 2, pp. 34-49, 2012.

[6] H. A. Roy, J. S. Wenger, T. D. Fletcher et al., "Impediments and solutions to sustainable, watershed-scale urban stormwater management: lessons from Australia and the United States," Environmental Management, vol. 42, no. 2, pp. 344-359, 2008.

[7] Gold Coast City Council, Water Sensitive Urban Design Guidelines, Policy 11, Section 13, Gold Coast City Council, Queensland Government, Australia, 2005.

[8] N. R. Siriwardene, A. Deletic, and T. D. Fletcher, "Clogging of stormwater gravel infiltration systems and filters: insights from a laboratory study," Water Research, vol. 41, no. 7, pp. 1433-1440, 2007.

[9] M. Dechesne, S. Barraud, and J. P. Bardin, "Experimental assessment of stormwater infiltration basin evaluation," Journal of Environmental Engineering, vol. 131, no. 7, pp. 1090-1098, 2005.

[10] S. K. Yazdi and M. Scholz, "Combined bio-filtration, water detention and infiltration system treating road runoff," in Proc. the $10^{\text {th }}$ British Hydrological Symposium, Exeter, UK, pp. 353-358, 2008.

[11] C. H. Emerson, B. M. Wadzuk, and R. G. Traver, "Hydraulic evaluation and total suspended solids capture of an infiltration trench," Hydrological Processes, vol. 24, no. 8, pp. 1008-1014, 2010.

[12] B. E. Hatt, T. D. Fletcher, and A. Deletic, "Treatment performance of gravel filter media: implications for design and application of stormwater infiltration systems," Water Research, vol. 41, no. 12, pp. 2513-2524, 2007.

[13] Department of Planning and Local Government, Water Sensitive Urban Design Technical Manual for Greater Adelaide Region, Department of Planning and Local Government, South Australian Government, Australia, 2009.
[14] M. Roldin, O. Mark, G. Kuczera, P. S. Mikkelsen, and P. J. Binning, "Representing soakaways in a physically distributed urban drainage model - Upscaling individual allotments to an aggregated scale," Journal of Hydrology, vol. 414-415, pp. 530-538, 2012.

[15] Logan City Council, Standards for Stormwater, Overland Flow and Flood Plain Management, Logan City Council, Queensland Government, Australia, 2010.

[16] F. Ahammed, "An investigation into the feasibility of stormwater management using WSUD principles in Dhaka, Bangladesh," PhD thesis, University of South Australia, 2014.

[17] Bureau of Meteorology, Climate Data Online: Average Annual: Seasonal and Monthly Rainfall, Australian Bureau of Meteorology, 2015.

[18] A. Tennakoon and J. R. Argue, "Managing urban regrowth with an at capacity stormwater infrastructure," in Proc. the $34^{\text {th }}$ IAHR World Congress and 33 ${ }^{\text {rd }}$ Hydrology and Water Resources Symposium, Brisbane, Australia, 2011, pp. 2720-2727.

[19] Auckland City Council, Soakage Design Manual, Auckland City Council, New Zealand, 2003.

[20] D. Browne, A. Deletic, G. M. Mudd, and T. D. Fletcher, "A new saturated/unsaturated model for stormwater infiltration systems," Hydrological Processes, vol. 22, no. 25, pp. 4838-4849, 2008.

[21] Construction Industry Research and Information Association, Infiltration Drainage-Manual for Good Practice: CIRIA Report 156, London, 1996.

[22] A. P. Davis, W. F. Hunt, R. G. Traver, and M. Clar, "Bioretention technology: overview of current practice and future needs," Journal of Environmental Engineering, vol. 135 no. 3, pp. 109-117, 2009.

[23] H. L. Ahuja, Business Economics, S. Chand \& Company, India, 2005.

[24] J. R. Meredith and S. J. Mantel, Project Management: A Managerial Approach, John Wiley \& Sons, 2006.

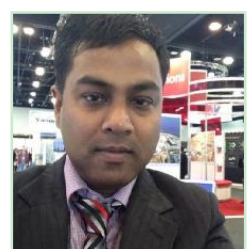

Faisal Ahammed is currently working as a lecturer of civil engineering at the University of South Australia (UniSA). He obtained his PhD degree on water engineering from UniSA in 2014. His current research focuses on infrastructure compliant stormwater management strategies for developed and developing countries. 